Reprod. Nutr. Dévelop., 1986, 26 (2 B), 619-631.

\title{
Changes in energy metabolism during the suckling and weaning period in the newborn
}

\author{
P. FERRÉ, J.-F. DECAUX, T. ISSAD, J. GIRARD
}

Centre de Recherches sur la Nutrition, C.N.R.S., 9, rue Jules Hetzel, 92190 Meudon-Bellevue, France.

\begin{abstract}
Summary. In most of the mammals, birth and weaning are two periods of nutritional transitions. Whereas the fetus oxidizes mainly glucose, lactate and aminoacids, the newborn is fed with milk, a high fat, low carbohydrate diet. At weaning, milk is replaced progressively by the adult diet which contains less fat and more carbohydrate. In the hours and days following birth, the newborn adapts itself to the new nutritional environment by increasing its capacity to produce glucose de novo (gluconeogenesis) in order to satisfy its high glucose needs. Oxidation of fatty acids is enhanced in the liver and at the peripheral level. Ketone bodies synthetized from fatty acids in the liver in large amounts are utilized by other tissues and specially the brain where they can met energetic and synthetic needs. In the rat, during the suckling period, lipogenesis is decreased in the liver and in white adipose tissue and triglyceride accretion is minimized. At weaning, these adaptations are reversed: decreased gluconeogenic and oxidative capacity of the liver, decrease of the role of ketone bodies, increase of the lipogenic rate in the liver and the adipose tissue, storage of triglycerides. The nutritional and hormonal factors involved in these metabolic adaptations are numerous but insulin and glucagon might play a major role.
\end{abstract}

\section{Introduction.}

In most of the mammals, the fetal-neonatal and the suckling-weaning transitions are attended by marked nutritional changes. The fetus uses mainly glucose, aminoacids and lactate as oxidative fuels, whereas fatty acids do not contribute significantly to fetal oxidative metabolism (Battaglia and Meschia, 1978 ; Girard et al., 1985). After birth, the newborn is fed with milk which, in most of the species, can be classified in term of energy delivered as a high fat, low carbohydrate diet (table 1) although this trend is less marked in humans. At weaning, the young mammal is fed with a diet in which the contribution of fat decreases whereas that of carbohydrate increases. In order to adapt to the changing nutritional environment, the newborn and the young undergo modifications of their energy metabolism. According to the species, these changes are not equivalent. Indeed, both milk composition and the degree of maturity of the animal at birth are different. This review will primarly focuse on the rat, since the informations gathered in this 
species allow to draw a coherent picture. When data are available concerning the human, they will also be discussed.

TABLE 1

Milk composition in various mammalian species expressed as \% of total calories.

\begin{tabular}{lccc}
\hline \multicolumn{1}{c}{ Species } & Lipid & Carbohydrate & Protein \\
\hline Rat & 69 & 6 & 25 \\
Dog & 63 & 12 & 25 \\
Guinea-pig & 62 & 10 & 28 \\
Pig & 59 & 15 & 26 \\
Rabbit & 58 & 5 & 37 \\
Human & 53 & 41 & 6 \\
\hline
\end{tabular}

\section{Suckling and weaning pattern in the laboratory rat.}

The newborn rat begins to suckle between 1 and 2 hrs after birth. Until 15 days of age, milk constitutes the only source of water and nutrients. Then, the newborn begins to nibble at the laboratory chow provided to the mother and drink tap water, and the amount of milk ingested progressively decreases (fig. 1). Between 28 and 30 days after birth, weaning is achieved and the young is fed with the laboratory chow.

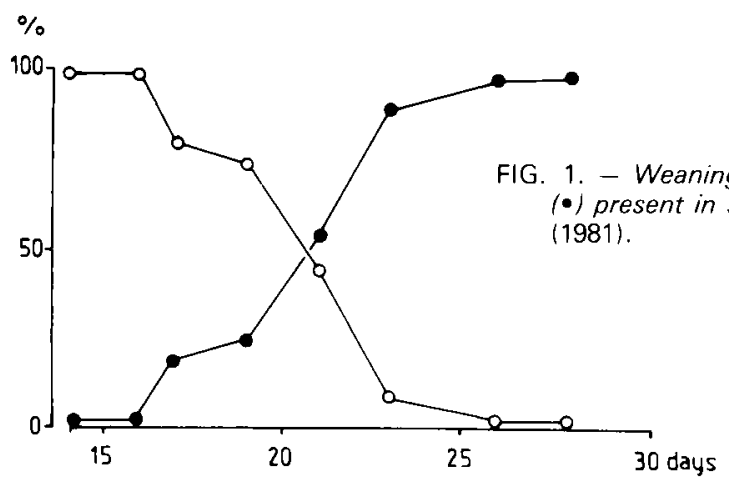

\section{Carbohydrate metabolism.}

In the adult mammals, glucose is an obligatory oxidative substrate for tissues such as red blood cells, renal medulla, retina, intestinal mucosa and the nervous system, although glucose utilization in brain can be partially replaced by ketone body oxidation (see section 3-4). During the suckling period, both in the rat and in the human, the brain is in a period of active growth. Thus, the maintenance of a normal blood glucose concentration is of primary importance for the development of the newborns. In the suckling rat, glucose homeostasis is maintained despite the very low amount of carbohydrate provided by the milk (table 1). Since glu- 
cose homeostasis results from an equilibrium between glucose utilization and glucose production, we will discuss successively these two parameters.

2.1. Glucose utilization. - The rate of glucose utilization, measured in anaesthetized 10-14-day old rats by isotope dilution techniques is in the range of $12-15 \mathrm{mg} / \mathrm{min} / \mathrm{kg}$ (Walker and Snell, 1973 ; Issad, Ferré and Girard (unpublished results)I, i.e. 1.5 to 2 -times higher than in the postabsorptive anaesthetized adult rat. A higher rate of glucose utilization is also found in the human newborn and infant when compared to the adult man (Bier et al., 1977; Bougnères et al., 1985). The presence of a brain which in newborns represents a much higher proportion of body-weight than in adults and which has a high rate of glucose utilization might partially explain this feature. For instance, in man, glucose utilization is linearly correlated to the brain weight throughout development and adulthood (Bier et al., 1977). In keeping with this, it has been reported that in infants with a reduced cerebral mass (anencephaly or hydrancephaly), the glucose turnover rate per $\mathrm{kg}$ body-weight was similar to that of adults (Schwartz and Kahlan, 1975). A high rate of glucose utilization in the suckling newborn in face of a low alimentary glucose intake implies that the newborn must produce large amounts of endogenous glucose.

2.2. Glucose production. - The main organ producing glucose is the liver. Two pathways can contribute to glucose production : the degradation of glycogen (glycogenolysis) which is stored in period of exogenous glucose availability and the de novo synthesis of glucose (gluconeogenesis) from precursors such as lactate, amino acids, galactose and glycerol. At term, the mammalian fetal liver contains large amounts of glycogen which are rapidly mobilized during the first $12 \mathrm{hrs}$ following birth (Shelley, 1961). The rapid onset of liver glycogenolysis at birth allows to maintain a normal blood glucose concentration in the newborn before other sources of energy become available. In the rat, the hepatic glycogen content remains low during the suckling period and increases only after weaning (Walker and Snell, 1973) (fig. 2). Thus, the contribution of liver glycogenolysis to glucose production during the suckling period is very low. Several lines of evidence suggest that gluconeogenesis is extremely active in the liver of the suckling

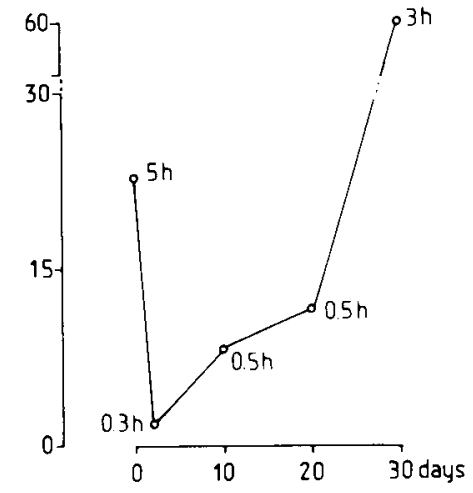

FIG. 2. - Hepatic glycogen content (mg/animal) in the rat during the suckling and weaning periods. Near each time-point figures the autonomy (hrs) in term of glucose utilization, given by the hepatic glycogen content. Adapted from Walker and Snell, 1973. 
rat. When specific inhibitors of gluconeogenesis are injected into suckling rats, a profound hypoglycaemia develops rapidly (Ferré, Pégorier and Girard, 1977 ; Ferré and Williamson, 1978). In contrast, in fed adult rats, these compounds do not produce hypoglycaemia (Di Tullio et al., 1974). Measurement of the gluconeogenic capacity of rat liver in vivo or in vitro indicates that gluconeogenesis is absent from the fetal liver, increases during the first hours following birth, remains 2-3fold higher during the suckling period than in the starved adults and decreases progressively at weaning to reach adult levels 30 days after birth (Phillipidis and Ballard, 1969 ; Beaudry, Chiasson and Exton, 1977 ; Ferré et al., 1981). This pattern is similar to the one observed for the activity of the key enzymes of gluconeogenesis and specially phosphoenolpyruvate carboxykinase (Ballard and Hanson, 1967 ; Vernon and Walker, 1968).

In human newborns, studies with stable isotopes have shown that gluconeogenesis from lactate, glycerol and alanine occurs at a significant rate within the first 8 hrs of life (Kahlan et al., 1980 ; Frazer et al., 1981 ; Bougnères et al., 1982). Moreover, congenital deficit of one of the specific enzymes of gluconeogenesis leads even in fed newborns to episodes of severe hypoglycaemia (Pagliara et al., 1972 ; Hommes et al., 1976 ; Vidnes and Sovik, 1976).

The relative contribution of gluconeogenesis to glucose homeostasis of the suckling newborns can also be estimated by comparing the exogenous supply of glucose via the milk and the rate of glucose utilization. These two parameters have been measured in human (Gentz, Kellum and Persson, 1976 ; Kahlan et al., 1976 ; Bier et al., 1977) and rat (Chalk and Bailey, 1979 ; Ferré et al., 1980) and indicate that glucose supplied from the milk covers respectively $50 \%$ and $20 \%$ of the glucose requirements of the human and rat newborns. Thus gluconeogenesis is an essential process to maintain normoglycaemia in the breast-fed infant or suckling rat.

The relative contribution of different substrates to gluconeogenesis in the neonate is not well known. It is unlikely that amino acids contribute to a great extent to glucose synthesis since they must be utilized for the active protein synthesis. The glycerol esterified in the triglycerides is also a possible precursor. In the human newborn, glycerol could contribute to $15 \%$ of the glucose synthetized de novo (Bougnères et al., 1982).

Lactate which comes from the incomplete oxidation of glucose in various tissues is a good gluconeogenic precursor in the newborn rat (Ferré et al., 1980). Finally the galactose moiety of lactose can also serve as a gluconeogenic precursor ; indeed during the suckling period, the enzymes of galactose metabolism are fully developed and galactose clearance rate is higher than glucose clearance rate (Kliegman and Sparks, 1985).

\section{Lipid metabolism.}

3.1. Fat absorption. - After birth and during the suckling period, newborn mammals are provided with large amounts of fat. More than $90 \%$ of milk fat are in the form of triglycerides and, in many species and particularly the rat, the milk contains significant amounts of medium-chain fatty acids (Dils and Parker, 1982). 
Whereas long-chain fatty acids are absorbed from the small intestine as chylomicrons, medium-chain fatty acids are preferentially absorbed from the stomach as free acids due to the presence of a lingual lipase, reaching then directly the liver by the portal vein (Hamosh, 1979 ; Aw and Grigor, 1980 ; Fernando - Warnakulasuriya et al., 1981) and are thus preferentially oxidized by this organ.

3.2. Lipid utilization by extra-hepatic tissues. - In the rat, during the suckling period, plasma non-esterified fatty acids (NEFA) and triglyceride concentrations are very high and decrease after weaning (Page, Krebs and Williamson, 1971 ; Foster et Bailey, 1976a ; Robles-Valdes, McGarry and Foster, 1976). Moreover, in heart, skeletal muscle and brown adipose tissue, the capacity to take up fatty acids from plasma triglycerides is high during suckling since lipoprotein lipase activity is elevated (Hémon, Ricquier and Mory, 1975; Cryer and Jones, 1978a, 1978b). At weaning lipoprotein lipase activity decreases in skeletal muscles and brown adipose tissue but remains elevated in the heart (Cryer and Jones, 1978a, 1978b). In white adipose tissue, lipoprotein lipase activity reaches a peak at mid-lactation then decreases, before to increase again at weaning (Cryer and Jones, 1978a). This has been interpreted as a consequence of cell proliferation during suckling followed by cell growth after weaning (Cryer and Jones, 1978a). The high lipoprotein lipase activity at mid-suckling is not correlated with an accretion of lipids in white adipose tissue, suggesting that other factors such as lipogenesis (see § 3-5) and lipolysis might affect fat deposition (Cryer and Jones, 1978a).

The capacity to oxidize long-chain fatty acids in extra-hepatic tissues is low in the fetal rat heart, skeletal muscle, kidney and small intestine but increases shortly after birth (Warshaw, 1972, 1974 ; Glatz and Veerkamp, 1982 ; Freund, Sedraoui and Geloso, 1984). It has been suggested that this is linked to a low activity during the fetal life of carnitine acyltransferase, the enzyme which catalyzes the entry of long-chain acylCoa inside the mitochondria, followed by its increase after birth, as well as to the increased concentration of its obligatory cofactor, carnitine, provided to the newborn via the milk (Robles-Valdes, McGarry and Foster, 1976 ; Borum, 1978 ; Hahn and Skala, 1972 ; Caroll et al., 1983). After weaning, the capacity to oxidize NEFA remains elevated in heart (Warshaw, 1972) ; kidney (Freund, Sedraoui and Geloso, 1984) and to a lesser extent in skeletal muscle (Glatz and Veerkamp, 1982).

3.3. Lipid oxidation in the liver. - In the liver, lipid oxidation fills two purposes : ATP generation for liver own energetic needs but also ketone body synthesis. Ketone bodies are then released into the blood and carried to the extrahepatic tissues where they are utilized (Robinson and Williamson, 1980; Williamson, 1982). In the fetal rat liver, NEFA oxidative capacity is low; it increases during the first 12 hrs after birth, remains high during the suckling period to decrease at weaning (Sly and Walker, 1978 ; Benito, Whitelaw and Williamson, 1979 ; Ferré et al., 1983 ; Decaux et al., 1985). Changes in the liver capacity to oxidize NEFA are paralleled by changes in the activity of the mitochondrial enzymes of $B$ oxidation and ketone body synthesis (Foster and Bailey, 1976b: Chalk et al., 1983 ; Shah and Bailey, 1977). The high oxidative capacity of liver during suck- 
ling, together with the high availability of NEFA in the plasma lead to high ketonebody blood concentrations which decrease after weaning (Lockwood and Bailey, 1971 ; Foster and Bailey, 1976a). As described in the \$ 3-4, this increased rate of ketogenesis by the liver is accompanied by a rise in the rate of peripheral utilization. Thus, suckling hyperketonemia does not reflect a defect in ketone body utilization. In the human newborn, in the hours following birth, blood ketone body concentrations are high (Bougnères et al., 1985). This is linked to an active synthesis of ketone bodies in the liver since in human newborns fasted for $4 \mathrm{hrs}$ (a physiological interval in current-nursery practice) ketogenesis reaches the rates of ketogenesis observed in adults after several days of fasting (Bougnères et al., 1985). The active ketogenesis is backed by a rapid and important mobilization of fat stores as shown by the high NEFA turnover rates in these infants (Bougnères et al., 1982).

3.4. Ketone body utilization. - It is now well established that ketone bodies are excellent substrates for peripheral tissues and can replace in part glucose in brain both for energetic and synthetic (lipid synthesis) purposes (Williamson and Buckley, 1973). In rat brain the activity of the enzymes implied in ketone body utilization are higher during the suckling period than in adult brain (Williamson and Buckley, 1973) and are also higher than in other tissues on a weight-basis (Page, Krebs and Williamson, 1971; Lockwood and Bailey, 1971). Measurements of arterio-venous differences for ketone bodies across the brain of suckling and adult rats have shown an increased removal of ketone bodies during the suckling period (Hawkins, Williamson and Krebs, 1971). In the human newborn, ketone body utilization is high and can met roughly $25 \%$ of the minimal energy requirement on the first days of life (Bougnères et al., 1986). Moreover, for a similar blood concentration, ketone-body utilization is 2-fold higher than in the adult. This higher ketone-body clearance rate can be linked to the large brain size in relation to body weight, a brain which possesses high activities of the specific enzymes of ketone body utilization (Page and Williamson, 1971; Tildon and Cornblath, 1972). Indeed, the brain of young infants takes up more ketone bodies than the adult brain (Persson, Settergren and Dahlquist, 1972; Kraus, Schlenker and Schwedesky, 1974).

3.5. Lipid synthesis. - In rats, in contrast with lipid oxidation, lipid synthesis is low in the liver during the suckling period but increases at weaning to reach adult values (Taylor, Bailey and Bartley, 1967 ; Benito, Whitelaw and Williamson, 1979). This is correlated with a low activity of the lipogenic enzymes in the liver and specially acetylCoA carboxylase (Lockwood, Bailey and Taylor, 1970) during the suckling period, followed by a large increase at weaning. The availability of NEFA will by itself decrease the lipogenic rate since long-chain acylCoA are potent inhibitors of the acetylCoA carboxylase reaction (Halestrap and Denton, $1973,1974)$. The lipogenic rate is also low in brown adipose tissue and increases after weaning (Pillay and Bailey, 1982). This suggests that during the suckling period, the high thermogenic activity of this tissue (Himms-Hagen, 1976) is supported by the oxidation of circulating triacylglycerol fatty acids. In white adipose tissue, the lipogenic rate is low during the suckling period (Tsujikawa and Kimura, 
1980 ; Gandemer, Pascal and Durand, 1982) and increases at weaning. This phenomenon is concomitant of fat accretion (Cryer and Jones, 1978a).

In conclusion, during the suckling period, the availability of lipids from exogenous sources is important. Lipids and ketone bodies, their hepatic derivative serve oxidative purposes, allowing to meet the elevated energetic needs of the growing organism. Ketone bodies can also act as lipogenic precursors in the developing brain.

\section{Glucose-lipid inter-relationships.}

In addition to the fact that lipid can replace glucose as an oxidative substrate in many tissues, thus sparing carbohydrates, lipid oxidation interferes with glucose metabolism at both production and utilization sites. Although lipids cannot provide carbons for de novo glucose synthesis, their hepatic oxidation is a prerequisite for an active gluconeogenic process both in the rat (Pégorier, Ferré and Girard, 1977 ; Ferré et al., 1978, 1979) and in the human (Bougnères et al., 1981). NEFA oxidation provides energy and the necessary cofactors for gluconeogenesis (Ferré et al., 1979). In the rat, at the peripheral level, lipid oxidation decreases glucose oxidation by inactivating pyruvate dehydrogenase (Pégorier et al., 1978 ; 1983) and thus increases lactate production from glucose and its availability as a gluconeogenic precursor (Cori cycle). A similar mechanism has been postulated in the human newborn oxidizing ketone bodies (Bougnères et al., 1983).

In conclusion, lipid oxidation increases glucose production both by a direct effet on gluconeogenesis and by increasing lactate availability. It also decreases glucose utilization thus reducing the need for gluconeogenic precursors and specially aminoacids which can then be used for protein synthesis.

\section{Nutritional and hormonal control of metabolic adaptations.}

Many hormonal and metabolic factors participate to the regulation of metabolism during this period and some regulatory mechanisms even anticipate the changes in the nutritional environment (Greengard, 1971; Henning, 1981). We have chosen to focus on the role of insulin and glucagon since, in adult mammals, the pattern of secretion of insulin and glucagon play a fundamental role in the adaptation of glucose and lipid metabolism to changing nutritional conditions.

Insulin and glucagon exert opposite actions upon hepatic metabolism ; glucagon promotes glucose production by increasing glycogenolysis and gluconeogenesis while insulin can inhibit glucose production and cause glucose storage ; glucagon stimulates NEFA oxidation and ketone body synthesis and inhibits lipogenesis whereas insulin has the reverse effects. At the peripheral level, insulin inhibits lipolysis, activates lipogenesis and increases glucose utilization in insulindependent tissues. 
During the immediate postnatal period, a significant increase in plasma glucagon occurs in rat and human neonates (fig. 3) (Girard et al., 1977). During the same period, insulin falls or remains low (fig. 3); these changes seem to be brought about by an adrenergic stimulation of the pancreas linked to the stress associated with birth (Girard et al., 1977). The suckling period in the rat is characterized by high plasma glucagon and low insulin levels (fig. 3), an hormonal environment found also in breast-fed infants (Girard et al., 1977). When the rats are weaned on the laboratory chow, plasma glucagon decreases and insulin increases (fig. 3) and a direct relationship between the new diet and the hormonal environment has been shown (Girard et al., 1977). It is then clear that this hormonal pattern can at least partially account for the metabolic adaptations observed during the suckling (fig. 3) and weaning periods. This is illustrated in the following examples.
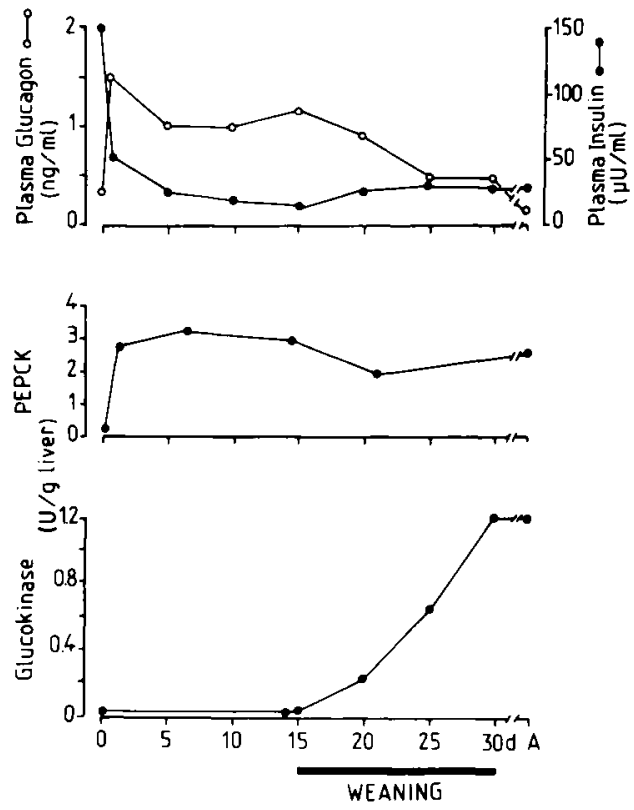

FIG. 3. - Plasma insulin and plasma ghucagon concentrations, liver phosphoenolpyruvate carboxykinase (PEPCK) and glucokinase activities during development in the rat. Redrawn from Walker and Holland (1965), Ballard and Hanson (1967), Girard et al. (1977).

Phosphoenolpyruvate carboxykinase is one of the key enzymes of gluconeogenesis. Its activity is barely detectable in the liver of the fetal rat but it increases up to starved adult activities within the first day of life (fig. 3) (Ballard and Hanson, 1967). The premature induction of this enzyme can be obtained in utero by injection of glucagon or cAMP to the fetus and the postnatal increase in liver PEPCK can be suppressed by injection of insulin to the newborn (Yeung and Oliver, 1968a, b ; Girard et al., 1977). Moreover, the injection of cAMP to the fetus causes a 20 -fold increase in the level of translatable Phosphoenolpyruvate carboxykinase mRNA in fetal liver, an increase which is normally observed in the hours following birth (Garcia-Ruiz, Ingram and Hanson, 1978). Thus, it is likely that, at birth, the fall of plasma insulin and the increase in plasma glucagon are responsible for the increase in hepatic phosphoenolpyruvate carboxykinase activity. 
Glucokinase, a glucose-phosphorylating enzyme, present only in hepatocytes allows the phosphorylation of glucose in a substrate-dependent manner since its $\mathrm{Km}$ is in the $10 \mathrm{mM}$ range and since its activity is not inhibited by glucose-6phosphate. In contrast to phosphoenolpyruvate carboxykinase, the activity of liver glucokinase is absent during the suckling period and increases dramatically at weaning (fig. 3) (Walker and Holland, 1965). This is accompanied at weaning by a corresponding increase in the amount of glucokinase mRNA (Spence, 1983). In the adult rat, glucose, insulin and glucagon exert a positive (insulin and glucose) or negative (glucagon) control upon glucokinase activity (Niemeyer, Perez and Rabajille, 1966 ; Sibrowski and Seitz, 1984). In the suckling rat, precocious induction of glucokinase can be obtained in 13-day old rat by oral glucose administration; this is counteracted by manno-heptulose (Wakelam, Allen and Walker, 1980), an inhibitor of insulin release. Moreover, alloxan diabetes retards the normal appearance of glucokinase at weaning (Walker and Holland, 1965). Finally, the normal development of glucokinase activity can be impaired by weaning the rat on a high-fat diet (Walker and Eaton, 1967), a condition in which the low plasma insulin/glucagon ratio persists (Girard et al., 1977). Thus, the pattern of secretion of the pancreatic hormones plays an important role, although not exclusive (Wakelam, Allen and Walker, 1980) in the development of glucokinase activity.

\section{General conclusion.}

In the rat, the total amount of calories provided to the animal is nearly similar on a weight basis during the mid-suckling period and in the newly-weaned animal (in the range of $0.3-0.4 \mathrm{Kcal} / \mathrm{g} /$ day). Thus, only the type of oxidative substrate is different. The suckling period is characterized by a high lipid availability and a high lipid oxidation whereas, after weaning, carbohydrates are the major oxidative substrate, leading to a specific adaptation of glucose metabolism during the suckling period, namely a high endogenous glucose production through gluconeogenesis. It implies that, when lipids are oxidized, and in presence of a normal protein availability, a high plasma insulin is not a prerequisite for an active growth and protein synthesis. Supply of lipids rather than carbohydrate might be advantageous when the volume of nutrients which can be provided to an organism is limited (for instance parenteral nutrition) and when an active protein synthesis is required. This area warrants further research.

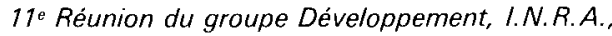
Montpellier, 22-24 mai 1985.

Acknowledgments. - We wish to thank Dr P. H. Duée for reviewing this paper and Mrs Fernandez for preparing the manuscript. The personal work presented in this review was supported by grants from "Ministère de I'Industrie et de la Recherche " (ATP 53-82 and 83-C-0448). 
Résumé. Le métabolisme énergétique du nouveau-né et du jeune au cours de l'allaitement et du sevrage.

Chez la plupart des mammifères, la naissance et le sevrage sont deux périodes de transition nutritionnelle. Alors que le fœtus oxyde essentiellement du glucose, du lactate et des acides aminés, le nouveau-né est nourri avec un régime riche en graisses et pauvre en glucides, le lait. Au sevrage, le lait est remplacé progressivement par le régime de l'adulte qui contient moins de graisses et plus de glucides. Dans les heures et les jours qui suivent la naissance, le nouveau-né s'adapte à son nouvel environnement en augmentant sa capacité à produire du glucose de novo (gluconéogenèse) afin de satisfaire les besoins élevés de ses tissus pour ce substrat. L'oxydation des acides gras au niveau hépatique et périphérique est également stimulée. Les corps cétoniques, synthétisés en grande quantité dans le foie à partir des acides gras sont utilisés par d'autres tissus et en particulier le cerveau où ils peuvent servir de substrat oxydatif et lipogénétique. Chez le rat, pendant la période d'allaitement, la lipogenèse est diminuée dans le foie et le tissu adipeux blanc et le stockage de triglycérides est faible. Au sevrage, ces adaptations sont progressivement inversées, diminution des capacités gluconéogénétiques et oxydatives du foie, de l'importance des corps cétoniques, augmentation de la lipogenèse dans le foie et le tissu adipeux blanc, stockage de triglycérides. Les facteurs nutritionnels et hormonaux impliqués dans ces adaptations métaboliques sont nombreux mais l'insuline et le glucagon pourraient jouer un rôle majeur.

\section{References}

AW T. Y., GRIGOR M. R., 1980. Digestion and absorption of milk triacylglycerols in 14-day old suckling rats. J. Nutr., 110, 2133-2140.

BALLARD F. J., HANSON R. W., 1967. Phosphoenolpyruvate carboxykinase and pyruvate carboxylase in developing rat liver. Biochem. J., 104, 866-871.

BATTAgliA F. C., MESCHIA G., 1978. Principal substrates of fetal metabolism. Physiol. Rev., 58, 499-527.

BEAUDRY M. A., CHIASSON J. L., EXTON J. H., 1977. Gluconeogenesis in the suckling rat. Am. J. Physiol., 233, E175-E180.

BENITO M., WHITELAW E., WILLIAMSON D. H., 1979. Regulation of ketogenesis during the suckling-weaning transition in the rat. Studies with isolated hepatocytes. Biochem. J., 180, 137-144.

BIER D. M., LEAKE R. D., HAYMOND M. W., ARNOLD K. J., GRUENKE L. D., SPERLING M. A., KIPNIS D. M., 1977. Measurement of « true » glucose production rates in infancy and childhood with 6,6-dideuteroglucose. Diabetes, 26, 1016-1023.

BORUM P. R., 1978. Variation in tissue carnitine concentration with age and sex in the rat. Biochem. J., 176, 677-681.

BOUGNĖES P. F., SAUdUBRAY J. M., MARSAC C., BERNARD O., ODIEVRE M., GIRARD J., 1981. Fasting hypoglycemia resulting from carnitine palmitoyl transferase deficiency. $J$. Pediatrics, 98, 742-746.

BOUGNĖRES P. F., KARL I. E., HILLMAN L. S., BIER D. M., 1982. Lipid transport in the human newborn. Palmitate and glycerol turnover and the contribution of glycerol to neonatal hepatic glucose output. J. clin. Invest., 70, 262-270.

BOUGNERES P. F., FERRE P., CHAUSSAIN J. L., JOB J. C., 1983. Glucose metabolism in hypersinsulinemic infants : the effects of fasting and sodium D, L- $\beta$-hydroxybutyrate on glucose production and utilization rates. J. clin. Endocr. Metab., 57, 1054-1060.

BOUGNERES P. F., ARTAVIA-LORIA E., FERRE P., CHAUSSAIN J. L., JOB J. C., 1985. Effects of hypopituitarism and growth hormone replacement on the production and utilization of glucose in childhood. J. clin. Endocr. Metab. (in press).

BOUGNERES P. F., LEMMEL C., FERRE P., BIER D. M., 1986. Ketone body transport in the human neonate and infants. J. clin. Invest. (in press).

CARROL J. E., SHUMATE J. B., VILLADIEGO A., CHOKSI R. M., MORSE D. P., 1983. Skeletal muscle fatty acid oxidation during early postnatal development in the rat. Biol. Neonate, $\mathbf{4 3}$, 191-197. 
CHALK P. A., BAILEY E., 1979. Changes in the yield, and carbohydrate, lipid and protein content of milk during lactation in the rat. $J$. develop. Physiol., 1, 61-79.

CHALK P. A., HIGHAM F. C., CASWELL A. M., BAILEY E., 1983. Hepatic mitochondrial fatty acid oxidation during the perinatal period in the rat. Int. J. Biochem., 15, 531-538.

CRYER A., JONES H. M., 1978a. Changes in the lipoprotein lipase (clearing-factor lipase) activity of white adipose tissue during development of the rat. Biochem. J., 172, 319-325.

CRYER A., JONES H. M., 1978b. Developmental changes in the activity of lipoprotein lipase (Clearing Factor Lipase) in rat lung, cardiac muscle, skeletal muscle and brown adipose tissue. Biochem. J., 174, 447-451.

DECAUX J. F., FERRÉ P., ROBIN P., ROBIN D., GIRARD J. R., 1985. Evolution du métabolisme hépatique des acides gras chez le rat au cours du sevrage. Reprod. Nutr. Dévelop., 25, 329330.

DILS R. R., PARKER D. S., 1982. Metabolic aspects of lactation and the supply of nutrients to the young, 573-590. In C.T. JONES, Biochemical development of the fetus and neonate, Elsevier, Amsterdam.

DI TULLIO N. W., BERKOFF C. E., BLANK B., KOSTOS V., STACK E. J., SAUNDERS H. L., 1974. 3-mercaptopicolinic acid, an inhibitor of gluconeogenesis. Biochem. J., 138, 387-394.

FERNANDO-WARNAKULASURYA G. J. P., STAGGERS J. E., FROST S. C., WELLS M. A., 1981. Studies on fat digestion, absorption and transport in the suckling rat. 1). Fatty acid composition and concentrations of major lipid components. J. Lip. Res., 22, 668-674.

FERRÉ P., PÉGORIER J. P., GIRARD J. R., 1977. The effect of inhibition of gluconeogenesis in suckling newborn rats. Biochem. J., 162, 209-212.

FERRE P., WILLIAMSON D. H., 1978. Evidence for the participation of aspartate aminotransferase in hepatic glucose synthesis in the suckling newborn rat. Biochem. J., 176, 335-338.

FERRE P., PÉGORIER J. P., MARLISS E. B., GIRARD J. R., 1978. Influence of exogenous fat and gluconeogenic substrates on glucose homeostasis in the newborn rat. Am. J. Physiol., 234. E129-E136.

FERRE P., PEGORIER J. P., WILLIAMSON D. H., GIRARD J. R., 1979. Interactions in vivo between oxidation of non-esterified fatty acids and gluconeogenesis in the newborn rat. Biochem. J., 182, 593-598.

FERRÉ P., TURLAN P., GIRARD J. R., 1980. Glucose turnover and glucose-lactate interrelations in the newborn rat. J. develop. Physiol., 2, 373-387.

FERRÉ P., SATABIN P., EL MANOUBI L., CALLIKAN S., GIRARD J., $1981 . \quad$ Relationship between ketogenesis and gluconeogenesis in isolated hepatocytes from newborn rats. Biochem. J., 200, 429-433.

FERRE P., SATABIN P., DECAUX J. F., ESCRIVA F., GIRARD J., 1983. Development and regulation of ketogenesis in hepatocytes isolated from newborn rats. Biochem. J., 214, 937-942.

FOSTER P. C., BAILEY E., 1976a. Changes in hepatic fatty acid degradation and blood lipid and ketone body content during development of the rat. Enzyme, 21, 397-407.

FOSTER P. C., BAILEY E., 1976b. Changes in the activities of the enzymes of hepatic fatty acid oxidation during development of the rat. Biochem. J., 154, 49-56.

FRAZER T. E., KARL I. E., HILLMAN L. S., BIER D. M., 1981. Direct measurement of gluconeogenesis from $\left[2,3-{ }^{13} \mathrm{C}_{2}\right.$ ] alanine in the human neonate. Am. J. Physiol., 240, E615-E621.

FREUND N., SEDRAOUI M., GELOSO J. P., 1984. Fatty acid oxidation by developing rat kidney. Biol. Neonate, 45, 183-187.

GANDEMER G., PASCAL G., DURAND G., 1982. In vivo changes in the rates of total lipid and fatty acid synthesis in liver and white adipose tissues of male rats during postweaning growth. Int. J. Biochem., 74, 797-804.

GARCIA-RUIZ J. P., INGRAM R., HANSON R. W., 1978. Changes in hepatic messenger RNA for phosphoenolpyruvate carboxykinase (GTP) during development. Proc. nat. Acad. Sci. USA, 75, 4189-4193.

GENTZ J., KELLUM M., PERSSON B., 1976. The effect of feeding on oxygen consumption, $R Q$ and plasma levels of glucose, FFA, and D- $\beta$-hydroxybutyrate in newborn infants of diabetic mothers and small for gestational age infants. Acta paediatr. scand., 65, 445-454.

GIRARD J. R., FERRE P., KERVRAN A., PEGORIER J. P., ASSAN R., 1977. Role of the insulin/glucagon ratio in the changes of hepatic metabolism during development of the rat, 563 
581. In P. P. FOA, J. S. BAJAJ, N. L. FOA, Glucagon: its role in physiology and clinical medicine, Springer Verlag, New York.

GIRARD J., DUÉE P. H., FERRE P., PEGORIER J. P., ESCRIVA F., DECAUX J. F., 1985. Fatty acid oxidation and ketogenesis during development. Reprod. Nutr. Dévelop., 25, 303-319.

GLATZ J. F. C., VEERKAMP J. H., 1982. Postnatal development of palmitate oxidation and mitochondrial enzyme activities in rat cardiac and skeletal muscle. Biochim. biophys. Acta, 711, 327-335.

GREENGARD O., 1971. Enzyme differentiation in mammalian tissues. Assays Biochem., 7, 159-205.

HAHN P., SKALA J., 1972. Carnitine and brown adipose tissue metabolism in the rat during development. Biochem. J., 127, 107-111.

HALESTRAP A. P., DENTON R. M., 1973. Insulin and the regulation of adipose tissue acetylcoenzyme A carboxylase. Biochem. J., 132, 509-517.

HALESTRAP A. P., DENTON R. M., 1974. Hormonal regulation of adipose tissue acetyl-coenzyme A carboxylase by changes in the polymeric state of the enzyme. The role of long-chain fatty acyl-coenzyme A thiosters and citrate. Biochem. J., 142, 365-377.

HAMOSH M., 1979. Fat digestion in the newborn : role of lingual lipase and periduodenal digestion. Pediat. Res., 13, 615-622.

HAWKINS R. A., WILLIAMSON D. H., KREBS H. A., 1971. Ketone body utilization by adult and suckling rat brain in vivo. Biochem. J., 122, 13-18.

HÉMON P., RICQUIER D., MORY G., 1975. The lipoprotein lipase activity of brown adipose tissue during early post-natal development of the normal and hypothyroid rat. Hormon. Metab. Res., 7. 481-484.

HENNING S. J., 1981. Postnatal development : coordination of feeding, digestion and metabolism. Am. J. Physiol., 241, G199-G214.

HIMMS-HAGEN J., 1976. Cellular thermogenesis. Annu. Rev. Physiol, 38, 315-351.

HOMMES F. A., BENDIEN K., ELEMA J. D., BREMER H. J., LOMBECK I., 1976. Two cases of phosphoenolpyruvate carboxykinase deficiency. Acta paediatr. Scand., 65, 233-240.

KAHLAN S. C., SAVIN S. M., ADAMS P. A. J., 1976. Measurement of glucose turnover in the human newborn with glucose $\left(1-{ }^{13} \mathrm{C}\right)$. J. clin. Endocr. Metab., 43, 704-707.

KALHAN S. C., BIER D. M., SAVIN S. M., ADAM P. A. J., 1980. Estimation of glucose turnover and ${ }^{13} \mathrm{C}$ recycling in the human newborn by simultaneous $\left[1-{ }^{13} \mathrm{C}\right]$ glucose and $\left[6-6-{ }^{2} \mathrm{H}_{2}\right]$ glucose tracers. J. clin. Endocr. Metab., 50, 456-460.

KLIEGMAN R. M., SPARKS J. W., 1985. Perinatal galactose metabolism. J. Pediatrics (in press).

KRAUS H., SCHLENKER S., SCHWEDESKY D., 1974. Developmental changes of cerebral ketone body utilization in human infants. Hoppe-Sey/er's. Z. Physiol. Chem., 355, 164-170.

LOCKWOOD E. A., BAILEY E. 1971. The course of ketosis and the activity of key enzymes of ketogenesis and ketone body utilization during development of the postnatal rat. Biochem. J., 124, 249-254.

LOCKWOOD E. A., BAILEY E., TAYLOR C. B., 1970. Factors involved in changes in hepatic lipogenesis during development of the rat. Biochem. J., 118, 155-162.

NIEMEYER H., PEREZ N., RABAJILLE E., 1966. Interrelation of actions of glucose, insulin and glucagon on induction of adenosine triphosphate: D-hexose phosphotransferase in rat liver. J. biol. Chem., 241, 4055-4059.

PAGE M. A., WILLIAMSON D. H., 1971. Enzyme of ketone body utilization in human brain. Lancet II, vol. 66-68.

PAGE A., KREBS H. A., WILLIAMSON D. H., 1971. Activities of enzymes of ketone body utilization in brain and other tissues of suckling rats. Biochem. J., 121, 49-53.

PAGLIARA A. S., KARL I. E., KEATING J., BROWN B., KIPNIS D. M., 1972. Hepatic fructose-1,6diphosphatase deficiency: A cause of lactic acidosis and hypoglycemia in infancy. J. clin. Invest., 51, 2115-2123.

PÉGORIER J. P., FERRE P., GIRARD J. R., 1977. The effects of inhibition of fatty acid oxidation in suckling newborn rats. Biochem. J., 166, 631-634.

PÉGORIER J. P., FERRE P., LETURQUe A., GIRARD J., 1978. The metabolic effects of sodium dichloroacetate in the suckling newborn rat. Diabetologia, 15, 459-463.

PÉGORIER J. P., LETURQUE A., FERRE P., TURLAN P., GIRARD J., 1983. Effects of mediumchain triglyceride feeding on glucose homeostasis in the newborn rat. Am. J. Physiol., 244, E329-E334. 
PERSSON B., SETTERGREN G., DAHLQUIST G., 1972. Cerebral arteriovenous difference of acetoacetate and D- $\beta$-hydroxybutyrate in children. Acta paediatr. Scand., 61, 273-278.

PHILIPPIDIS H., BALLARD F. J., 1969. The development of gluconeogenesis in rat liver. Experiments in vivo. Biochem. J., 113, 651-657.

PILLAY D., BAILEY E., 1982. Perinatal lipogenesis in the liver and BAT of the rat. Int. J. Biochem., 14, 511-518.

ROBINSON A. M., WILLIAMSON D. H., 1980. Physiological roles of ketone bodies as substrates and signals in mammalian tissues. Physiol. Rev., 60, 143-187.

ROBLES-VALDES G., Mc GARRY J. D., FOSTER D. W., 1976. Maternal fetal carnitine relationships and neonatal ketosis in the rat. J. biol. Chem., 251, 6007-6012.

SCHWARTZ R., KAHLAN S., 1975. Energy sources for neonatal brain metabolism. In Progress in clinical and biological research, vol. 2, Preventability of perinatal injury. ADAMSONS K., FOX H. A. (eds), pp. 187-200, A. R. Liss Inc., New York.

SHAH J., BAILEY E., 1977. Changes in the activities of the enzymes of hepatic ketogenesis in the rat between late fetal life and weaning. Enzyme, 22, 35-40.

SHELLEY H. J., 1961. Glycogen reserves and their changes at birth and in anoxia. Brit. Med. Bull., 17, 137-143.

SIBROWSKI W., SEITZ H. J., 1984. Rapid action of insulin and cyclic AMP in the regulation of functional messenger RNA coding for glucokinase in rat liver. J. biol. Chem., 259, 343-346.

SLY M. R., WALKER D. G., 1978. A Comparison of lipid metabolism in hepatocytes isolated from fed and starved neonatal and adult rats. Comp. Biochem. Physiol., 61, 501-506.

SPENCE J. T., 1983. Levels of translatable mRNA coding for rat liver glucokinase. J. biol. Chem., 258, 9143-9146.

TAYLOR C. B., BAILEY E., BARTLEY W., 1967. Changes in hepatic lipogenesis during development of the rat. Biochem. J., 105, 717-722.

TILDON J. T., CORNBLATH M., 1972. Succinyl-CoA: 3-ketoacid CoA transferase deficiency. A cause for ketoacidosis in infancy. J. clin. Invest, 51, 493-498.

TSUJIKAWA M., KIMURA S., 1980. Changes in lipid synthesis in rat adipose tissue during development. J. Nutr. Sci. Vitaminol., 26, 367-374.

VERNON R. G., WALKER D. G., 1968. Changes in activity of enzymes involved in glucose utilisation and glucose formation in developing rat liver. Biochem. J., 106, 321-329.

VIDNES J., SOVIK O., 1976. Gluconeogenesis in infancy and childhood. III. Deficiency of the extramitochondrial form of hepatic phosphoenolpyruvate carboxykinase in a case of persistent neonatal hypoglycaemia. Acta paediatr. Scand., 65, 307-312.

WAKELAM M. J. O., ALLEN M. B., WALKER D. G., 1980. Factors that prevent the premature appearance of glucokinase in neonatal rat liver. Biochem. J., 186, 817-826.

WALKER D. G., EATON S. W., 1967. Regulation of development of hepatic glucokinase in the neonatal rat by the diet. Biochem. J., 105, 771-777.

WALKER D. G., HOLLAND G., 1965. The development of hepatic glucokinase in the neonatal rat. Biochem. J., 97, 845-854.

WALKER D. G., SNELL K., 1973. The role of gluconeogenesis in neonatal metabolism, 97-117. In HOMMES F. A., VAN DEN BERG C. J. Inborn errors of metabolism. Acad. Press, London.

WARSHAW J. B., 1972. Cellular energy metabolism during fetal development. IV. Fatty acid activation, acyl transfer and fatty acid oxidation during development of the chick and rat. Develop. Biol., 28, 537-544.

WARSHAW J. B., 1974. Fatty acid oxidation during development, 88-97. In H. H. BODE, J. B. WARSHAW, Parental nutrition in infancy and childhood, Plenum Publ. Corp., New York.

WILLIAMSON D. H., BUCKLEY B. M., 1973. The role of ketone bodies in brain development, 8196. In HOMMES F. A., VAN DEN BERG C. J., Inborn errors of metabolism, Acad. Press, New York.

WILLIAMSON D. H., 1982. The production and utilization of ketone bodies in the neonate, 621650. In C. T. JONES, Biochemical development of the fetus and neonate, Elsevier, Amsterdam.

YEUNG D., OLIVER I. T., 1968a. Factors affecting the premature induction of phosphopyruvate carboxylase in neonatal rat liver. Biochem. J., 108, 325-331.

YEUNG D., OLIVER I. T., 1968b. Induction of phosphopyruvate carboxylase in neonatal rat liver by adenosine 3' : 5' cyclic monophosphate. Biochemistry, 7, 3231-3239.

Reproduction, Nutrition, Développement, $n^{\circ} 2$ B-86. -8 